\title{
Zastosowanie śródoperacyjnej ultrasonografii u pacjentów z nowotworami trzustki
}

\section{The use of intraoperative ultrasound in patients with pancreatic neoplasms}

\author{
Grzegorz Ćwik, Michał Solecki, Andrzej Dąbrowski, Grzegorz Wallner \\ II Katedra i Klinika Chirurgii Ogólnej, Gastroenterologicznej i Nowotworów Układu Pokarmowego Uniwersytetu Medycznego \\ w Lublinie
}

Prz Gastroenterol 2013; 8 (4): 230-236

DOI: $10.5114 /$ pg.2013.37484

Słowa kluczowe: ultrasonografia śródoperacyjna, diagnostyka, nowotwory trzustki.

Key words: intraoperative ultrasonography, diagnosis, pancreatic neoplasms.

Adres do korespondencji: dr hab. med. Grzegorz Ćwik, Klinika Chirurgii Ogólnej, Gastroenterologicznej i Nowotworów Układu Pokarmowego, SPSK 1, ul. Staszica 16, 20-081 Lublin, tel.: +48 8153241 27, faks: +48 8153288 10, e-mail: grzegorzcwik@poczta.fm

\begin{abstract}
Streszczenie
Śródoperacyjna ultrasonografia (intraoperative ultrasonography - IOUS) umożliwia potwierdzenie i weryfikację rozpoznania przedoperacyjnego. W wielu przypadkach pozwala na prawidłowe ustalenie stopnia zaawansowania choroby, bezpieczne przeprowadzenie zabiegu chirurgicznego oraz skrócenie jego czasu trwania. Prawidłowa ocena struktur anatomicznych w czasie operacji i pola operacyjnego po zakończeniu zabiegu w połączeniu z ich badaniem ultrasonograficznym umożliwiają pełniejszą ocenę radykalności leczenia. W Klinice, w której pracują autorzy, śródoperacyjne badanie ultrasonograficzne jest stosowane w codziennej praktyce. W niniejszej pracy pragniemy podzielić się własnymi doświadczeniami w zastosowaniu tej techniki obrazowania.

Śródoperacyjna ultrasonografia jest wiarygodnym badaniem w ocenie zarówno zmian zapalnych, jak i nowotworowych $w$ trzustce. Prawidłowo wyznacza zakres planowanej operacji. W przypadku raka trzustki weryfikuje miejscowy stan zaawansowania zmian guzowatych za pomocą oceny zajęcia układu naczyń okołotrzustkowych, węzłów chłonnych oraz obecności przerzutów miejscowych i odległych. Metoda ta okazała się wysoce skuteczna w ocenie guzów endokrynnych oraz torbielowatych trzustki. Badanie znacznie poprawia skuteczność śródoperacyjnej biopsji oraz aspiracji.
\end{abstract}

Ultrasonografia śródoperacyjna (intraoperative ultrasonography - IOUS) po raz pierwszy została zastosowana na początku lat 60 . XX w., jeszcze w prezentacji $A$, kiedy to Knight i Newell wykorzystali ją w diagnostyce jamy brzusznej, w badaniu kamicy pęcherzyka żółciowego i dróg żółciowych [1]. W latach 80. ubiegłego wieku, już po wprowadzeniu prezentacji $B$, Lane i Glazer w czasopiśmie „Lancet” opisali IOUS jako przydatną metodę

\begin{abstract}
Intraoperative ultrasonography allows for the confirmation and verification of preoperative diagnosis. In many cases, correct determination of the severity of the disease allows surgery to be performed safely and shortens its duration. Proper evaluation of the anatomical structures during the operation and evaluation of the surgical field after completing the operation in combination with ultrasound allows for better assessment of radicality of the treatment. On the ward in which the authors are working, intraoperative ultrasound is used in everyday practice. In this paper we wish to share our experience in applying this imaging technique.

Intraoperative ultrasonography is a reliable test in evaluating both inflammation and neoplastic lesions of the pancreas. It correctly determines the extent of the planned operation. In the case of pancreatic cancer, it verifies clinical stage, assessing involvement of peripancreatic vessels, lymph nodes and the presence of local and distant metastases. Intraoperative ultrasonography has proved highly effective in the evaluation of endocrine and cystic tumors of the pancreas. The procedure significantly improves the effectiveness of intraoperative biopsy and aspiration.
\end{abstract}

w badaniu patologicznych zmian w obrębie trzustki [2]. Od tego czasu nastąpił znaczny postęp $\mathrm{w}$ technologii pojawiły się najnowsze aparaty ultrasonograficzne (USG) o olbrzymiej rozdzielczości, wyposażone w nowoczesne, wielofunkcyjne głowice i oprogramowanie umożliwiające dokładne odczytanie obrazu badanego narządu. Badanie ultrasonograficzne nabrało znaczenia nie tylko diagnostycznego, nastąpił znaczący rozwój ultra- 
sonografii zabiegowej, w tym ultrasonografii laparoskopowej (laparoscopic ultrasonography - LUS) [3-5].

Obecnie istnieje duży wybór aparatury służącej do IOUS. Wykorzystywane są różnego typu sondy o określonym przeznaczeniu, odpowiednim kształcie oraz charakterystyce wytwarzanego sygnału. Do badania trzustki stosuje się sondy o wysokiej częstotliwości, głównie w zakresie 7,5-10 MHz [4, 6, 7], a ich kształt i wielkość są dopasowane do możliwości oceny narządu w dwóch wymiarach - podłużnym i poprzecznym. Obecnie używa się najczęściej sond o kształcie „T” lub „””, są to zwykle głowice typu convex, rzadziej sektorowe lub liniowe. Sprzęt musi być łatwy do sterylizacji oraz prosty w obsłudze.

W celu przeprowadzenia śródoperacyjnej oceny trzustki należy ją w odpowiedni sposób uwolnić z otaczających struktur, gdyż tylko bezpośrednie przyłożenie głowicy do narządu umożliwia prawidłowe jego zobrazowanie i wychwycenie nawet drobnych szczegółów budowy oraz zmian chorobowych $[4,8]$. Gdy nie udaje się za pomocą metod chirurgicznych dotrzeć do samej trzustki, możliwe jest badanie USG narządu poprzez lewy płat wątroby lub okno akustyczne wytworzone przez uciśniętą ścianę żołądka [4]. Jak się wydaje, aby w takich warunkach dokładniej zobrazować głowę trzustki i otaczające ją struktury, należy przyłożyć sondę poprzez dwunastnicę, nawet od strony bocznej, kierując ją w stronę żyły wrotnej. Oceniając głowę trzustki, należy zwrócić uwagę na takie struktury anatomiczne, jak wyrostek haczykowaty trzustki, żyła wrotna i spływ krezkowo-wrotny oraz tętnica krezkowa górna. W kolejnych badaniach obrazuje się elementy więzadła wątrobowo-dwunastniczego - przewód żółciowy wspólny i struktury naczyniowe, kolejno pęcherzyk żółciowy oraz kierując się ku lewej części narządu, duże naczynia tętnicze, naczynia śledzionowe oraz wnękę śledziony [4, 7, 8].

Echogeniczność miąższu trzustki jest oceniana jako nieznacznie większa w stosunku do tkanki wątrobowej. Zależy ona od wieku pacjenta, ale głównie od zawartości elementów włóknistych oraz tłuszczowych [4, 9]. Wzmożona echogeniczność jest charakterystyczna dla przewlekłego zapalenia trzustki, w którym to procesie wzrasta ilość elementów włóknistych oraz zwapnień, przy redukcji prawidłowego miąższu narządu [4, 10]. Obfita tkanka tłuszczowa okolicy pozaotrzewnowej oraz nacieczenie nią samej trzustki może u części pacjentów powodować trudności w zobrazowaniu brzegu badanego narządu. Wydaje się, że w takich warunkach pomocne jest określenie położenia przylegających struktur naczyniowych, biegnących wzdłuż trzustki oraz krzyżujących ją [4].

Ultrasonografia śródoperacyjna jest coraz częściej wykorzystywana w trakcie zabiegów w obrębie trzustki. Stosuje się ją głównie w przypadku zmian guzowatych, nowotworowych, ale także w ostrych i przewlekłych zapaleniach trzustki $[9,11]$. Zasadniczym zadaniem jest uwidocznienie zmian ogniskowych, określenie ich charakteru i granicy oraz pobranie materiału biotycznego w trakcie operacji. Technika ta umożliwia zróżnicowanie zmian torbielowatych, lito-torbielowatych i litych w trzustce oraz w jej sąsiedztwie $[4,8,11]$. Ważnym elementem jest ocena wtórnych zmian powstałych w przebiegu zarówno procesów zapalnych trzustki, jak i w wyniku ekspansji raka trzustki, z możliwością zajęcia węzłów chłonnych oraz wzrostu przerzutów nowotworu.

W II Katedrze i Klinice Chirurgii Ogólnej, Gastroenterologicznej i Nowotworów Przewodu Pokarmowego IOUS stosuje się z powodzeniem od 1996 r. W tym czasie wykonano ponad 500 badań, głównie z powodu różnych schorzeń wątroby oraz trzustki. W obrazowych badaniach przedoperacyjnych wykorzystywano USG przezskórne, włącznie z badaniem dopplerowskim, wielorzędową tomografię komputerową (TK), rzadziej rezonans magnetyczny (magnetic resonance imaging - MRI). W wielu przypadkach wykonano również przezskórną biopsję aspiracyjną cienkoigłową (BAC). U pacjentów z potwierdzoną pierwotną chorobą dotyczącą trzustki w większości przypadków przyczyną zastosowania IOUS były guzy podejrzane o rozrost nowotworowy. W mniejszym procencie przypadków przeprowadzono badanie w celu śródoperacyjnej oceny zmian w przebiegu ostrego oraz przewlekłego zapalenia trzustki. Od 2007 r. IOUS wykonywano z użyciem aparatury BK Medical System Pro Fockus, w tym sondy 5-12 MHz o podłużnym kształcie „,", przystosowanej do śródoperacyjnej biopsji i ablacji. Wcześniej do tego celu wykorzystywano sondę liniową i ultrasonograf Hitachi EUB 410. Przed każdym zabiegiem sonda była sterylizowana $w$ odpowiednich płynach antyseptycznych, do badania wykorzystywano jednorazowe pokrowce, osłony używane także w laparoskopii. W trakcie badania ocenie poddawano całą trzustkę, od głowy obrazowanej przez dwunastnicę i z bezpośredniego przyłożenia sondy do narządu, po nacięciu torby sieciowej i uwolnieniu wszystkich zrostów od wysokości krzywizny żołądka do nasady krezki poprzecznicy. Następnie ocenie poddawano trzon oraz ogon trzustki, dochodząc do wnęki śledziony. Zwracano uwagę na zrazikową budowę miąższu, wymiary, przylegające naczynia, włącznie z oceną przepływu w badaniu dopplerowskim. Oceniano również wszystkie zmiany patologiczne dotyczące trzustki, jej otoczenia, impresji lub naciekania struktur naczyniowych oraz w przypadku zmian nowotworowych, na zajęcie układu chłonnego okołotrzustkowego oraz na to, czy doszło do powstania dalszych przerzutów, głównie w obrębie wątroby i w dalszych węzłach chłonnych. W przypadkach o nieznanej naturze zmian w trzustce, przy podejrzeniu przemiany 
nowotworowej oraz pozapalnej wykonywano w trakcie IOUS i pod jej nadzorem BAC zmian ogniskowych oraz pobranie tkanki przy śródoperacyjnym obrazowaniu.

Niniejszy artykuł jest próbą określenia obecnych wskazań do zastosowania IOUS w leczeniu zmian chorobowych trzustki na podstawie doświadczeń własnych oraz przytaczanego piśmiennictwa.

Śródoperacyjna ultrasonografia jest użyteczną techniką, pomagającą rozwiązywać problemy w chirurgii trzustki, w trakcie resekcji wątroby i w rozmaitych leczniczo-diagnostycznych procedurach podczas laparotomii $[7,12,13]$. Śródoperacyjna ultrasonografia oraz LUS są obecnie najczęściej stosowane w śródoperacyjnej ocenie wątroby, pęcherzyka żółciowego oraz patologii i budowy dróg żółciowych $[2,3,5,8]$. Podstawowym zadaniem jest ustalenie charakteru zmian ogniskowych wątroby oraz zakresu resekcji miąższu wątroby pod względem kryteriów onkologicznych oraz nadzór nad procedurami ablacyjnymi w przypadku guzów przerzutowych. Większość diagnozowanych przedoperacyjnie pierwotnych oraz wtórnych zmian nowotworowych o złośliwym charakterze nie kwalifikuje się do leczenia operacyjnego. Zastosowanie IOUS zmienia wcześniejsze plany operacyjne, oparte na przedoperacyjnych badaniach obrazowych, nawet w 38-49\% przypadków [1, 7, 8]. Spośród pacjentów z kolorektalnym rakiem u 5-12\% badanych wykrywa się najczęściej drobne lub obwodowo położone zmiany przerzutowe w wątrobie. Ważnym elementem badania jest również określenie zajęcia układu chłonnego na różnych jego piętrach, zarówno w jamie otrzewnowej, jak i przestrzeni pozaotrzewnowej [1, 3].

Zabiegi chirugiczne wykonywane na trzustce są w dalszym ciągu wyzwaniem dla chirurga. Ultrasonogra-

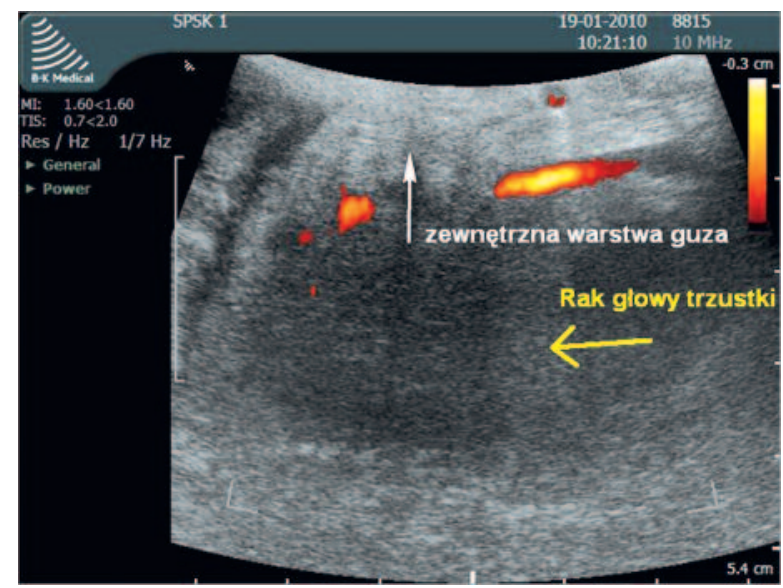

Ryc. 1. Badanie IOUS. Hipoechogeniczny guz rak trzustki. Zewnętrzna odczynowa warstwa guza

Fig. 1. IOUS. Hypoechoic mass - pancreatic carcinoma. The outer reactive layer of tumor fia śródoperacyjna w klasycznej oraz laparoskopowej wersji w istotny sposób wpływa na przebieg operacji. Obecnie wykorzystywana jest przy różnicowaniu zmian ogniskowych trzustki, głównie przewodowego raka trzustki oraz zmian zapalnych, guzów endokrynnych, torbielowatych, guzów wewnątrzprzewodowych (intraductal papillary mucinous neoplasm - IPMN) $[3,4,6,10$, 14]. Wydaje się, że najbardziej przydatna dla chirurga jest właściwa identyfikacja śródoperacyjna wyspiaków trzustki, rzadziej innych guzów endokrynnych [6, 13]. Obecnie zalecaną metodą, pomagającą w ich identyfikacji, jest badanie rozszerzone o obrazowanie dopplerowskie $[4,15]$. Duże nadzieje związane z zastosowaniem nowych, laparoskopowych głowic wiąże się z chirurgią guzów endokrynnych trzustki, nawet gdy była wykonana dokładna diagnostyka przedoperacyjna $[4,6,16]$. Ultrasonografia laparoskopowa umożliwia dokładne określenie zaawansowania raka trzustki, a przede wszystkim zobrazowanie zmian przerzutowych na powierzchni otrzewnej oraz powierzchownych zmian w wątrobie. Wykorzystanie ultrasonografii laparoskopowej włącznie z BAC poprawia skuteczność badania do wartości 88\% [5].

Pomimo poprawy przedoperacyjnych możliwości diagnostycznych w dalszym ciągu problemem są niedokładnie zróżnicowane zmiany guzowate w trzustce oraz zmiany uwidocznione dopiero w trakcie laparotomii [17, 18]. Śródoperacyjne badanie USG jest metodą z wyboru w przypadkach, gdy nie istnieją już inne, alternatywne metody diagnostyczne [12]. Wysoka rozdzielczość używanych sond śródoperacyjnych pozwala na prawidłowe uwidocznienie praktycznie całej trzustki. Możliwe jest to po bezpośrednim przyłożeniu sondy do badanego narządu [7, 17]. Rak trzustki może być otoczony zewnętrzną warstwą, w której nie stwierdza się obecności komórek nowotworowych. Może to być związane ze zwiększoną objętością podścieliska guza i tkanek odpowiadających utkaniu procesów wtórnych, zapalnych, współistniejących z nowotworem oraz zmianami degeneracyjnymi, martwiczymi $w$ przebiegu powiększania objętości guza (ryc. 1.) [18, 19]. Takie niejednolite echogenicznie obszary są odpowiednio uwidaczniane w IOUS i charakteryzują się znacznie większą czułością niż badanie palpacyjnie, które obarczone jest dużym procentem błędów diagnostycznych [7, 17, 20].

Diagnostyka nowotworów trzustki dotyczy głównie gruczolakoraka. Jest on najczęstszą postacią, szacunkowo może występować aż w 70-85\% guzowatych zmian $w$ trzustce. Zasadniczym celem ultrasonografii jest zobrazowanie guza, odróżnienie go od innych, najczęściej zapalnych lub pozapalnych zmian litych oraz przeprowadzenie kwalifikacji mającej na celu ustalenie sposobu postępowania leczniczego, co jest głównie uzależnione od zaawansowania choroby nowotworowej 


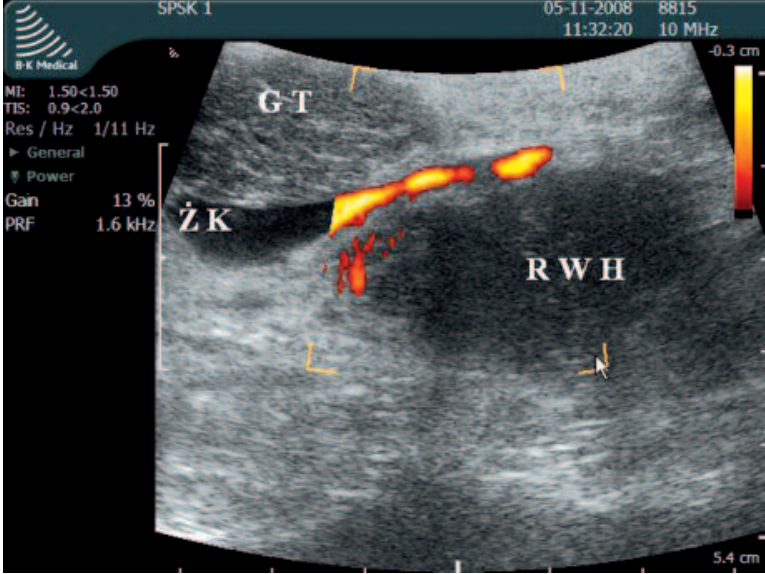

Ryc. 2. Badanie IOUS, Doppler mocy

GT - głowa trzustki, ŻK - żyła krezkowa górna, RWH - rak wyrostka haczykowatego trzustki (hipoechogeniczny)

Fig. 2. IOUS, power Doppler

GT - pancreatic head, ŻK - mesenteric superior vein, RWH - cancer of uncinate process (hypoechoic)

[3, 6, 9]. Ultrasonografia śródoperacyjna ma naturalną przewagę nad badaniem konwencjonalnym, co uwarunkowane jest bezpośrednim przyłożeniem głowicy do badanego narządu. Umożliwia to przecięcie więzadła żołądkowo-okrężniczego oraz mobilizacja dwunastnicy (manewr Kochera) [7]. Na tym etapie IOUS obejmuje cztery stopnie diagnostyczne: zobrazowanie zmiany ogniskowej, określenie stosunku zmiany do głównego przewodu trzustkowego, ocenę resekcyjności w odniesieniu do naczyń żylnych i tętniczych oraz ocenę wątroby i układu chłonnego $[6,7]$. W przypadku zmian w obrębie wyrostka haczykowatego należy zbadać możliwość naciekania żyły i tętnicy krezkowej górnej (ryc. 2.). Jeżeli zmiana dotyczy głowy trzustki, należy dokładnie ocenić żyłę krezkową górną, spływ krezkowo-wrotny, żyłę wrotną oraz tętnicę krezkową górną, żołądkowo-dwunastniczą i tętnice wątrobowe. Jeżeli kolejno ognisko znajduje się w okolicy cieśni, trzeba zbadać przebieg żyły krezkowej górnej, spływ krezkowo-wrotny, żyłę wrotną, tętnicę krezkową górną, wątrobową wspólną oraz pień trzewny. Przy położeniu zmiany ogniskowej w dystalnym odcinku trzonu i ogonie trzustki IOUS określa stosunek guza do naczyń śledzionowych na całej ich długości.

Ultrasonografia śródoperacyjna może służyć do wskazania optymalnego miejsca do wykonania diagnostycznej biopsji w trakcie operacji (ryc. 3.) [21]. Połączenie metody IOUS oraz biopsji cienkoigłowej lub gruboigłowej umożliwia osiągnięcie wysokiej trafności diagnostycznej, gdzie zarówno czułość, jak i swoistość wynosi 90-100\% [18-20]. Istotną zaletą IOUS jest ocena nacieku na naczynia okołotrzustkowe, spływu żyły wrotnej oraz tętnicy krezkowej górnej i pnia trzewnego.

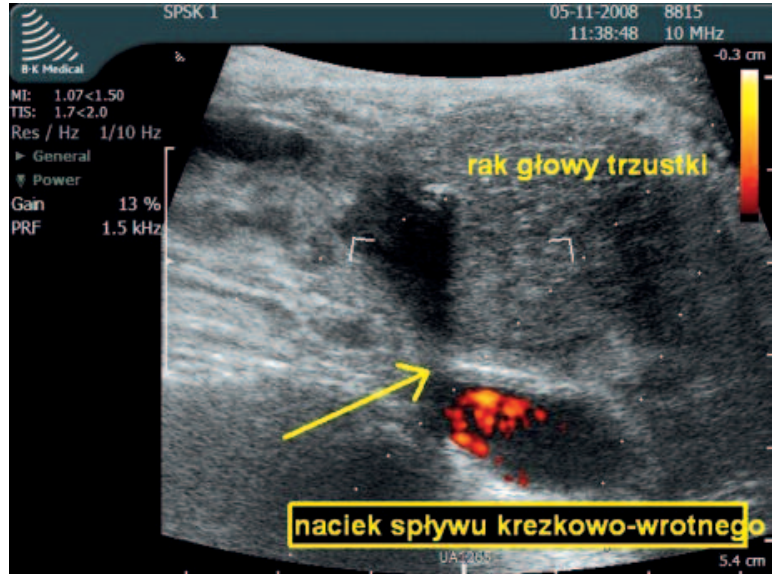

Ryc. 3. Badanie IOUS, hipoechogeniczny guz wyrostka haczykowatego trzustki - BACC. Guz nacieka spływ krezkowo-wrotny $(\downarrow)$

Fig. 3. IOUS, hypoechoic tumor of pancreatic uncinate process - FNAB. Tumor infiltrating portal confluence $(\downarrow)$

W jednym z pierwszych kompleksowych opracowań Machi i wsp. [15] wykazali znaczną przewagę czułości, specyficzności i dokładności IOUS w diagnozowaniu nacieku nowotworowego na spływ żyły wrotnej w porównaniu z badaniami przedoperacyjnymi - przezskórną USG, angiografią i TK. Przykładowo, dokładność IOUS określono na 89,7\% w porównaniu z 64,1\% wartości średniej pozostałych badań obrazowych. Współczesna wielorzędowa tomografia komputerowa (multi-rowdetector computed tomography - MDCT) umożliwia lepszą ocenę zaawansowania guza wraz oceną nacieku na naczynia. Czułość metody ocenia się na 90-98,4\%, jednak możliwość resekcji guza na podstawie MDCT cechuje się mniejszą czułością statystyczną (71,4-90\%) [6, 7, 11, 22]. Trafna ocena (czułość) naciekania układu naczyniowego w diagnostyce raka trzustki oparta na IOUS jest obecnie szacowana w granicach 92-93\%, przy podobnej swoistości próby wynoszącej średnio 95\% (ryc. 4.) [4, 6-8]. Badanie śródoperacyjne pozwala również na wiarygodne zobrazowanie powiększonych węzłów chłonnych okołotrzustkowych i dalszych (ryc. 5.). Są one trudne do odróżnienia, szczególnie przy istniejącym odczynie zapalnym, rozległym nacieku okolicznych struktur lub obfitej tkance tłuszczowej [7, 20]. Ze względu na możliwość bezpośredniego przyłożenia sondy do powierzchni narządu IOUS jest także najbardziej wiarygodną metodą oceny obecności przerzutów w wątrobie, w tym zmian wielkości od $5 \mathrm{~mm}[17,21]$. W badaniach stwierdzono wysoką czułość metody - jej uśredniona wartość wynosi około 94\% w porównaniu z 86,7\% przy zastosowaniu MRI $[6,7]$. W trakcie badania należy dokładnie ocenić całość miąższu, przykładając sondę do 


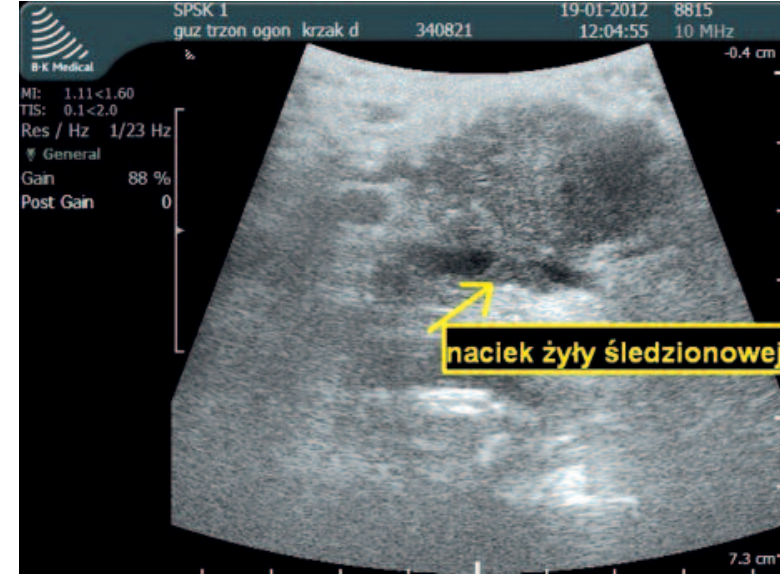

Ryc. 4. Badanie IOUS. Rak trzonu trzustki, nacieczenie żyły śledzionowej

Fig. 4. IOUS. Pancreatic body cancer, infiltration of the splenic vein

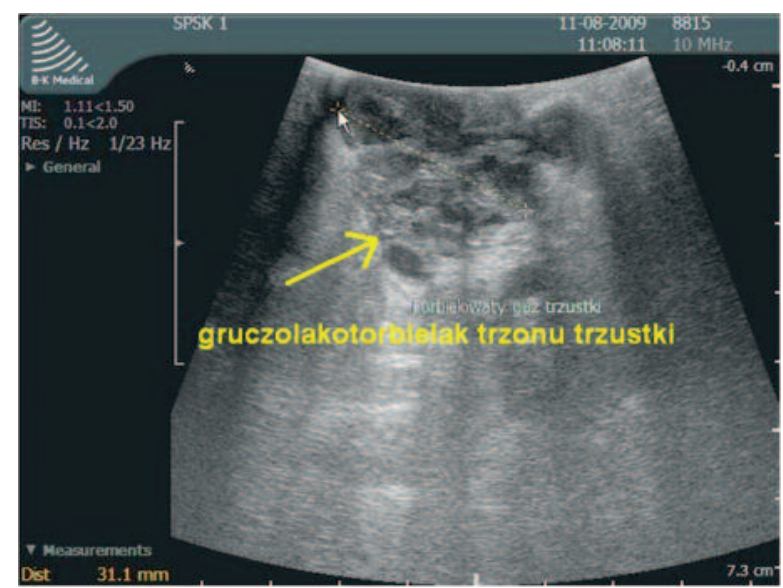

Ryc. 6. Badanie IOUS. Gruczolakotorbielak trzonu trzustki

Fig. 6. IOUS. Pancreatic body cystadenocarcinoma

przedniej powierzchni wątroby, kierując ją kolejno ku górze, w stronę kopuły, następnie do powierzchni dolnej oraz po puszczeniu często istniejących zrostów również do tylnej powierzchni narządu [7]. U pacjentów z resekcyjnym guzem w trzustce zobrazowanie problematycznej lub nieuwidocznionej $w$ badaniach przedoperacyjnych zmiany w wątrobie wymaga przeprowadzenia doraźnego badania bioptycznego wykonanego pod kontrolą IOUS [4, 7]. Biopsja aspiracyjna cienkoigłowa ma również duże znaczenie w przypadkach nieresekcyjnych, gdy ustalenie rozpoznania jest istotne przy wyznaczeniu dalszego postępowania terapeutycznego, również paliatywnego.

Oprócz zmian litych, w trzustce można rozpoznawać guzy o charakterze torbielowatym. Przyjmuje się obec-

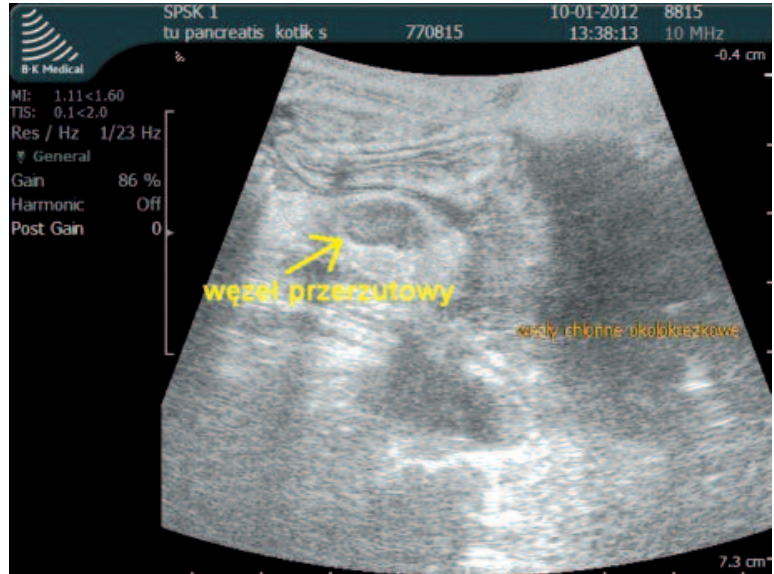

Ryc. 5. Badanie IOUS. Rak głowy trzustki. Przerzutowy węzeł w krezce jelita cienkiego

Fig. 5. IOUS. Pancreatic head cancer. Metastatic node in the mesentery of the small intestine

nie, że w 2-4\% torbielowatych zmian w trzustce mamy do czynienia z nowotworowymi guzami torbielowatymi [23, 24]. Za ich obecnością przemawiają pogrubienie ściany, często odcinkowe, powstanie guzków w ścianie lub w jej wnętrzu oraz zwapnienia. W badaniach obrazowych obserwuje się również obecność struktur groniastych w obszarze torbieli i wewnętrzne przegrody. Zalecanymi metodami, oprócz podstawowych badań obrazowych, są ultrasonografia endoskopowa (endoscopic ultrasound - EUS) oraz IOUS. Charakterystyczną cechą gruczolakotorbielaka surowiczego są liczne drobne torbiele, niekiedy z wewnętrznym zwapnieniem, tworzące policykliczne układy (ryc. 6.). Za obecnością IPMN przemawia uwidocznienie torbielowatego poszerzenia przewodu trzustkowego oraz wewnętrznych brodawczakowatych wyrośli, a za śluzotwórczym guzem torbielowatym - obecność zmiany torbielowatej o niejednorodnie pogrubiałej ścianie $[4,14,23,24]$. Ultrasonografia śródoperacyjna ma podstawowe znaczenie w operacyjnym leczeniu guzów torbielowatych. Ważne jest dokładne umiejscowienie zmiany. Należy pamiętać, że mogą to być guzy mnogie, nierozpoznane w badaniu przedoperacyjnym. Różna jest też patologia guzów torbielowatych, mogą to być formy łagodne oraz złośliwe, naciekające struktury otaczające i dające przerzuty, w tym do węzłów chłonnych i wątroby [4, 23, 24]. Zobrazowane zmiany typu IPMN mogą mieć również różny charakter. Postacie obwodowe są zwykle łagodne, podczas gdy dotyczące głównego przewodu trzustkowego - znacznie częściej są formami złośliwymi, inwazyjnymi [4, 14]. Resekcja trzustki częściowa lub całkowita jest jedyną metodą postępowania. Jej zakres wyznacza położenie guza, jego charakter oraz zobrazowane cechy w bezpo- 
średnim badaniu IOUS, włącznie ze śródoperacyjną biopsją kierowaną USG [4, 14, 23].

Ostatnią omawianą grupą są guzy neuroendokrynne trzustki, z których najczęstszą formą jest wyspiak trzustki. Są to zwykle zmiany pojedyncze, o wielkości do $1 \mathrm{~cm}$, w badaniu USG o znacznie lub częściowo obniżonej echogeniczności, jednorodne w budowie, dobrze odgraniczone (ryc. 7.) [4, 7, 9]. W części przypadków wyspiaki mogą być izoechogeniczne, czyli nie odróżniają się od pozostałego miąższu trzustki, co utrudnia wstępną diagnozę w badaniach obrazowych, głównie w przezskórnym USG. Ultrasonografia śródoperacyjna jest przy dużej rozdzielczości analizy badanego obrazu bardzo skuteczną metodą diagnostyczną dla małych, słabo odróżnicowanych guzów endokrynnych, o często nieuwidocznionej lokalizacji $[4,6,7,9,13,21]$. Gdy w przedoperacyjnych badaniach obrazowych nie udaje się ustalić położenia wyspiaka wydzielającego insulinę, można zastosować metodę selektywnego oznaczania stężenia insuliny w żyle wrotnej i jej rozgałęzieniach po wybiórczym zacewnikowaniu naczynia żylnego lub stężenia insuliny po wybiórczym podawaniu glukonianu wapnia do naczyń tętniczych, okołotrzustkowych na różnej ich wysokości [13]. Wydaje się, że u takich pacjentów najlepszym sposobem postępowania jest połączenie wiarygodnych metod diagnostyki przedoperacyjnej z techniką chirurgiczną, która umożliwia poprawne wykonanie IOUS [9, 13, 15]. Należy również pamiętać o możliwości występowania mnogich neuroendokrynnych ognisk guza oraz o rzadkiej lokalizacji pozatrzustkowej [13, 15, 21]. Ultrasonografia śródoperacyjna jest bardziej dokładną procedurą diagnostyczną niż TK lub MRI, a nawet niż ostatnio często zalecana ultrasonografia wzmacniana kontrastem (contrast enhanced ultrasound - CEUS). Czułość i swoistość badania określono na 90-96\%, a nawet niekiedy blisko 100\% [6, 7, 8, 13]. Procedura może być dokładniejsza przy zastosowaniu śródoperacyjnego badania dopplerowskiego [15]. We wszystkich wątpliwych przypadkach trzustka powinna być w trakcie operacji dokładnie uwolniona od otaczających struktur, zalecany jest również manewr Kochera, czyli mobilizacja dwunastnicy [7]. Do rzadziej diagnozowanych guzów neuroendokrynnych zalicza się glukagonomę, gastrinomę, VIP-omę, somastatynomę i rakowiaka $[4,8,13,14]$. Guzy te w obrazie USG są hipolub izoechogeniczne, zwykle - podobnie jak wyspiaki dobrze odgraniczone od miąższu trzustki. Częściej jednak występują zmiany o typie złośliwym, także z możliwością tworzenia ognisk przerzutowych.

Wydłużenie czasu zabiegu o kilka minut przeznaczonych na badanie USG jest pozorne. W rzeczywistości skraca się całkowity czas operacji - uzyskuje się dokładną ocenę bez konieczności rozległego preparowania tka-

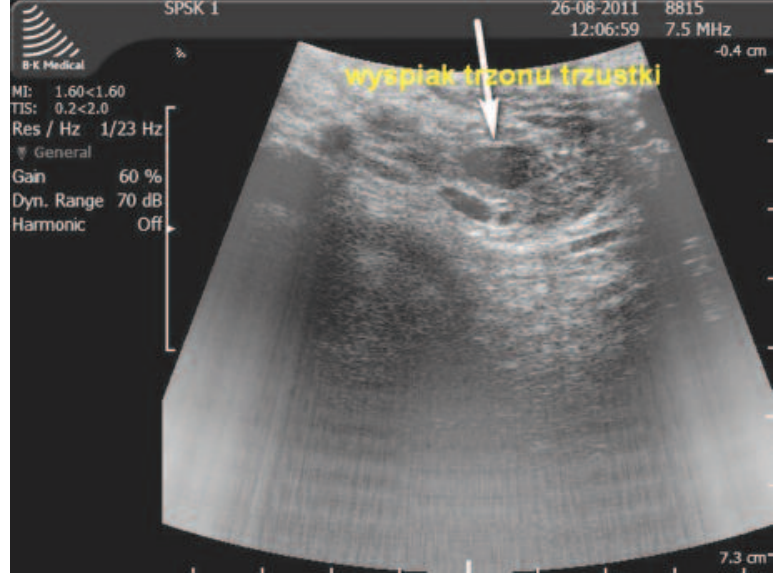

Ryc. 7. Badanie IOUS. Hipoechogeniczny, dobrze odgraniczony guz trzonu trzustki, $12 \mathrm{~mm}$. Wyspiak trzustki otoczony niezmienioną tkanką Fig. 7. IOUS. Hypoechoic, well-demarcated tumor body of the pancreas, $12 \mathrm{~mm}$. Pancreatic insulinoma surrounded by unaffected tissue

nek, a interpretacja wyniku badania nie zależy od innych specjalistów. Ze względu na wysoką czułość i swoistość metoda IOUS powinna być procedurą stosowaną rutynowo, szczególnie w referencyjnych ośrodkach chirurgicznych.

$\mathrm{Na}$ podstawie przytoczonego piśmiennictwa oraz własnych obserwacji omówiono wskazania do wykorzystania IOUS w chirurgii guzów trzustki, które obejmują: - określenie miejscowego zaawansowania raka trzustki (ocena naciekania naczyń, zajęcia układu chłonnego oraz cholestazy),

- ocenę wątroby pod względem istnienia zmian przerzutowych,

- obrazowanie małych guzów neuroendokrynnych w trzustce,

- różnicowanie guzów torbielowatych trzustki oraz torbieli rzekomych,

- różnicowanie guzów nowotworowych oraz nienowotworowych powstałych głównie w przebiegu procesów zapalnych trzustki,

- lokalizację i ocenę przewodu trzustkowego, jego stopnia poszerzenia i przyczyny nadciśnienia,

- identyfikację zakrzepicy żylnej w układzie naczyń wrotnych.

\section{Piśmiennictwo}

1. Kane RA. Intraoperative ultrasonography: history, current state of the art, and future directions. J Ultrasound Med 2004; 23: 1407-20.

2. Lane RJ, Glazer G. Intra-operative B-mode ultrasound scanning of the extra-hepatic biliary system and pancreas. Lancet 1980; 2: 334-7. 
3. Kulig J, Kołodziejczyk P, Sierżęga M. Ultrasonografia laparoskopowa i śródoperacyjna. Ultrasonografia 2008; 35: 9-12.

4. Sun MRM, Brennan DD, Kruskal JB, Kane RA. Intraoperative ultrasonography of the pancreas. Radiographics 2010; 30: 1935-53.

5. Mortensen MB, Fristrup C, Ainsworth A, et al. Laparoscopic ultrasound-guided biopsy in upper gastrointestinal tract cancer patients. Surg Endosc 2009; 23: 2738-42.

6. Long EE, Van Dam J, Weinstein S, et al. Computed tomography, endoscopic, laparoscopic, and intra-operative sonography for assessing resectability of pancreatic cancer. Surg Oncology 2005; 14: 105-13.

7. Kolecki R, Schirmer B. Intra-operative and laparoscopic ultrasound. Surg Clin North Am 1998; 78: 251-71.

8. Shin LK, Brant-Zawadzki G, Kamaya A, Jeffrey RB. Intraoperative ultrasound of the pancreas. Ultrasound Q 2009; 25: 39-48.

9. Mayo-Smith WW, Iannitti DA, Dupuy DE. Intraoperative sonographically guided wire cannulation of the pancreatic duct for patients undergoing a Puestow procedure. AJR 2000; 175: 1639-40.

10. Horwhat JD, Gress F. Defining the diagnostic algorithm in pancreatic cancer. JOP 2004; 5: 289-303.

11. D’Onofrio M, Vecchiato F, Faccioli N, Pozzi Mucelli R. Ultrasonography of the pancreas. 7. Intraoperative imaging. Abdom Imaging 2007; 32: 200-6.

12. Isla A, Arbuckle JD, Kekis BP, et al. Laparoscopic management of insulinomas. Br J Surg 2009; 96: 185-90.

13. Kaneko T, Nakao A, Inoue S, et al. Intraoperative ultrasonography by high-resolution annular array transducer for intraductal papillary mucinous tumors of the pancreas. Surgery 2001; 129: 55-65.

14. Hiramoto JS, Feldstein VA, Le Berge JM, Norton JA. Intraoperative ultrasound and preoperative localization detects all occult insulinomas. Arch Surg 2001; 136: 1020-6.

15. Machi J, Sigel B, Zaren HA, et al. Operative ultrasonography during hepatobiliary and pancreatic surgery. World I Surg 1993; 17: 640-5.

16. Kaczmarek B, Kostyrka R, Wójcicki M, Zieliński S. Śródoperacyjna ultrasonografia w chirurgii raka trzustki. Pol Przeg Chir 2000; 72: 37-41.

17. Ihse I, Axelson J, Dawiskiba S, Hansson L. Pancreatic biopsy: Why? When? How? World J Surg 1999; 23: 896-900.

18. Saez A, Catala I, Brossa R, et al. Intraoperative fine needle aspiration cytology of pancreatic lesions. Acta Cytol 1995; 39: 485-8.

19. Niederau C, Grendell JH. Diagnosis of pancreatic carcinoma. Imaging techniques and tumor markers. Pancreas 1992; 7: 66-86.

20. Benson MD, Gandhi MR. Ultrasound of the hepatobiliary-pancreatic system. World J Surg 2000; 24: 166-70.

21. Vargas R, Nino-Murcia M, Trueblood W, Brooke J Jr. MDCT in pancreatic adenocarcinoma: prediction of vascular invasion and resectability using a multiphasic technique with curved planar reformations. AJR 2004; 182: 419-25.

22. Ferrone CR, Correa-Gallego C, Warshaw AL, et al. Current trends in pancreatic cystic neoplasms. Arch Surg 2009; 144: 448-54.

23. Lipiński M, Degowska M, Rydzewska G. Zmiany torbielowate w trzustce. Prz Gastroenterol 2007; 2: 315-39.

24. Kalafat H, Mihmanli I, Saribeyoglu K, Belli A. Intraoperative doppler ultrasound: a reliable diagnostic method in insulinoma. Hepatogastroenterology 2007; 54: 1256-8. 